stressed the need for co-operation by both sides: without it we must fail. The question of research was particularly emphasized by $\mathrm{Mr}$. A. Albu, and, in replying on the debate, the Parliamentary Secretary to the Ministry of Transport, Vice-Admiral J. H. Hallett, said that the British Shipbuilding Research Association is ably directed and undertakes research into production methods and techniques. It is hoped that the two industries will now jointly evolve some wider research organization which can handle problems of operation and of design and building as a whole, including possibly research on Diesel engines.

\section{The Institution of Electrical Engineers}

MUCH of the scientific work of the Institution of Electrical Engineers has been for many years conducted by four specialized sections (electronics and communications, measurement and control, supply and utilization). It has now been decided that it will be advantageous for the four sections to be replaced. by three divisions, two of which will represent electronics and power interests, while the third, a general division, will cover activities of common interest to all electrical engineers, such as basic measurement, and technological education. Each of the divisions will comprise a number of technical groups designed to cover the specializations within its field, and the scheme provides for speedy re-adjustment and creation of those technical groups which will increase the flexibility which is now more than ever necessary to reflect the rapid developments of electrical science and engineering. In setting up a divisional structure, the Council has also recognized the increasing importance of electronics in electrical engineering, and the part being played by electronics engineers in the work of the Institution which has resulted in its present position as the professional home of electronics engineers.

\section{Australian Journal of Experimental Agriculture and Animal Husbandry}

THIs new journal is devoted to reports both on agronomy and animal husbandry. Judging from the contents of the first number, the journal is likely to cover a wide range of topics: it includes articles on the potassium content of some Western Australian soils, legumes in pastures, classification of Australian wheat varieties based on the granularity of their wholemeal and the relationships between digestibility of dry matter and digestibility energy content of ruminant diets. A pleasing feature is the inclusion of summaries of each paper in the list of contentsa departure which might be more widely followed. The journal is published quarterly by the Australian Institute of Agricultural Science for the Australian Agricultural Council and the subscription is $\mathbf{E A . 5}$ a year including postage.

\section{Index Biologicus}

UNDER the title Index Biologicus a periodical is being planned that will be a classified index of current papers from international literature in pure biology, giving titles, authors and journal references. It is intended that immediate notice will be given of all papers published in this already very extensive and rapidly expanding field, and that biologists will be provided with an information service comparable with those now available in other subjects, for example, Index Medicus, Current Chemical Papers and Chemical Titles. Scientific direction of the journal will be the responsibility of Biological and Medical Abstracts, Ltd., a non-profit company, limited by guarantee, that was formed by a number of learned societies when British Abstracts ceased publication so that the physiological and biochemical sections might be carried on. Like the present International Abstracts of Biological Sciences, which is the successor to Section A III of British Abstracts, the Index Biologicus will be published on a contractual basis for Biological and Medical Abstracts by the Pergamon Press. It is hoped that this publication will meet a real need and, moreover, it is expected that cooperation in the framing of scientific policy will be fortheoming from biological societies in Britain and overseas. The first issue of the journal is planned to appear in June 1962 or January 1963. Any comments or inquiries should be made to Dr. R. K. Callow, chairman, Biological and Medical Abstracts, Ltd., 4 Fitzroy Square, London, W.1.

\section{Museum of English and Rural Life}

ThE annual report for 1960 of the Museum of English Rural Life at the University of Reading welcomes an acquisition from the British Council of some 300 examples of traditional design and fine workmanship (Pp. 19. 5 plates. Reading: The University. 1961. 1s.). The collection includes saddlery, wrought ironwork, small stools, turnery, basket work, pottery and textiles, and is of special value because the names and locations of the makers were known. More storage space has helped the re-arrangement of the reserve material, and increased workshop facilities have speeded the restoration of the larger farm implements and vehicles. The report of this organization is always noteworthy for the inclusion of notes on policy and other matters affecting the museum movement. On this occasion the curator, Mr. C. A. Jewell, contributes notes for collectors concerning the acquisition of folk-life material. It is rightly stated that traditional rural life in England was based on a relatively close-knit and self-sufficient community often with a distinct regional character. Although this has largely disappeared, scattered evidence still survives and practical and useful details are given on the collecting of objects and recording of information. The report is well illustrated.

\section{Society for Folk-life Study}

Plans to form a Society for Folk-life Study will be discussed at a conference to be held in London during September 6-8, 1961. Membership will be open to all who are interested in the traditional patterns of life in both rural and urban communities, and especially in local dialects, crafts, folk-lore and customs. It is intended that the new Socioty will serve as a focus for the activities of all who take an interest in their cultural inheritance. Various wellknown experts in this field of study have promised to speak at the conference. Further information can be obtained from Mr. J. G. Jenkins, St. Fagans, $\mathrm{nr}$. Cardiff, who is the secretary of the steering committee.

\section{The Nitrogen Problem}

Prof. N. R. DhaR, in his presidential address to the forty-eighth Indian Science Congress held at Roorkee this year, reviewed the importance of nitrogen in crop production. He pointed out that synthetic nitrogen plants have been started in many 